\title{
University graduate satisfaction profile as an education quality criterion
}

\author{
Marina Viktorovna Pereverzeva ${ }^{1 *}$, Natalia Ivanovna Anufrieva ${ }^{1}$, Marina Gennadievna \\ Kruglova $^{1}$, Stanislav Nikolaevich Mikhaylov ${ }^{2}$, and Yana Mamontova ${ }^{1}$ \\ ${ }^{1}$ Russian State Social University, Arts Department, Moscow, Russia \\ ${ }^{2}$ The Academic Music School at the Moscow State Conservatory P.I. Tchaikovsky, Moscow, Russia
}

\begin{abstract}
Research background: Despite a fairly long tradition of measuring students' assessment of the quality of obtained university education, there are still many unresolved issues in this area. The aim of the study: to theoretically substantiate the concept of a profile of graduates' satisfaction with university educational programs including several parameters. The satisfaction profile serves as a criterion of the quality of education, at the same time reflecting students' subjective assessment of the learning outcomes received at the university that they correlate with their expectations at the stage of admission. The concept is proposed in association with the monitoring of university graduates' satisfaction with educational programs developed and tested as part of the research work at the Russian State Social University. Methods: graduate satisfaction is assessed using quantitative (questionnaires, the results of which are processed in SPSS) and qualitative (interviews) research methods. The proposed and tested method for the assessment of university graduates' satisfaction with educational programs can serve as a basis for the development of university systems for monitoring graduates' satisfaction with educational programs and education quality management and the satisfaction profile can become a universal criterion of education quality assessment not only in Russian but also in foreign universities. Results and novelty: The novelty and significance of the study results lie in the fact that the rating of educational process factors significant for graduates' satisfaction provides information that can be used for successfully placing the direction of training in the market of educational services. Moreover, two ratings of the importance of the identified factors are constructed. The first one reflects the respondents' direct assessment that can be used in advertising and information campaigns in the market of educational services. The second rating shows indirect assessment providing a more adequate image of the real impact of various factors on graduates' satisfaction with educational programs; the results of this rating can be used in the intra-university quality management.
\end{abstract}

* Corresponding author: melissasea@mail.ru 
Keywords: graduate satisfaction with the quality of education, education quality management, monitoring, higher education

\section{Introduction}

The assessment of university students' and graduates' satisfaction with the quality of educational programs is gradually becoming part of intra-university education quality management systems [1]. What is becoming the system-forming indicator of the quality of education is the satisfaction of the consumer - the graduate [2-4]. University education quality management systems predominantly focus on international organization quality assessment systems and the certification procedure is conducted in accordance with them. The most common reference point in Russia is ISO 9000:2000 (GOST ISO 9000-2001) [5]. Focus on the consumer is a fundamental principle in the construction of an effective and efficient management system in organizations including universities: "Quality management is aims for meeting customer requirements and striving to exceed their expectations", the implementation of this principle calls for "assessment and monitoring of consumer satisfaction and taking the appropriate action" [6].

However, despite a fairly long tradition of measuring the assessment of the quality of obtained education [7, 8], there are still many unresolved issues in this area. One of them consists in the lack of a well-established comprehensive assessment of graduate satisfaction with education. In the modern world, the problem of assessing university graduates' satisfaction with educational programs has to be posed and resolved through the unity of four aspects - the economic, the managerial, the pedagogical, and the ethical - which requires the corresponding adjustment of the research method proposed in the present study.

\section{Methods}

To make students' assessments more specific, we identify the factors (parameters, criteria) of education that, as we believe, compose this assessment: assessment of the material and technical support, assessment of the educational process management, assessment of the teachers' professional level, assessment of the relevance of the set of academic disciplines, assessment of the educational and industrial practice, assessment of conditions for creating an individual educational trajectory, for self-development, and self-improvement, and assessment of the level of psycho-emotional comfort during training. The parameters of graduates' self-esteem allowing us to make judgments on the education quality assessment are also identified and include self-assessment of the level of one's theoretical and practical professional training, salary expectations, and the degree of self-identification with the obtained profession. Salary expectations, the fact of employment in the profession, and willingness to recommend the university to one's acquaintances for obtaining higher education are also considered in the study as important indicators and components of the graduate satisfaction profile. The study also includes open-ended questions on the advantages and disadvantages of the educational programs and suggestions for their improvement which allows obtaining a wider range of subjective assessments of professional programs.

The satisfaction index is calculated by the formula: the average factor score divided by the maximum number of points on the scale of satisfaction with the factor (in our case, 3 ) and multiplied by $100 \%$ [9]. The questionnaire consists of 29 questions and the interview guide includes 35 questions. The participants in the pilot study are students of five directions of training within the enlarged group of specialties "Cultural Studies and Sociocultural Design" in one of the university departments. Revealing the correlation between the graduates' evaluation of the quality of education in general and by its individual parameters 
allows us to identify the parameters that play the predominant role in the subjective assessment of the quality of education obtained by the graduate. These parameters can be used as guidelines for the intra-university quality management system.

\section{$3 \quad$ Results}

\subsection{Satisfaction index}

The study sample includes 40 graduates from the years 2018-2020. The composition of the sample by the level of obtained education is as follows: Bachelor's graduates $-61.5 \%$; Master's graduates - $17.9 \%$; graduates of both Bachelor's and Master's degrees of the university $-20.5 \%$. The composition of the sample by the form of education: full-time $53.8 \%$; distance $-43.6 \%$; part-time $-2.6 \%$. The composition of the sample by the education financing type: budget $-87.2 \%$; contract $-12.8 \%$. According to the region of residence: Moscow and the Moscow Region - 94.9\%; regions of the Central Federal District of Russia $-2.6 \%$; regions of the Northwestern Federal District of Russia- $2.6 \%$.

The average index of satisfaction with education among the respondents is $73 \%$ (see Table 1). Considering satisfaction with the quality of educational programs by individual factors, the highest rating is given to the parameters of "development of interest and professional motivation" (satisfaction index $-87 \%$ ) and the "level of teaching" (satisfaction index $-79 \%$ ) while the lowest rating is received by the parameters of "educational and industrial practice" (satisfaction index -60\%) and "management" (satisfaction index - 64\%). Considering that the study results show that $68 \%$ of the graduates are generally satisfied with their practical training, the improvement of the practice bases is quite realistic and does not call for special overpowering managerial efforts.

Table 1. Satisfaction index by parameters (in \%)

\begin{tabular}{|c|c|c|c|c|}
\hline Parameters & $\begin{array}{c}\text { Bachelor's } \\
\text { Degree }\end{array}$ & $\begin{array}{c}\text { Master's } \\
\text { Degree }\end{array}$ & $\begin{array}{c}\text { Bachelor's } \\
\text { and Master's } \\
\text { Degree }\end{array}$ & Total \\
\hline $\begin{array}{c}\text { Overall assessment of } \\
\text { education }\end{array}$ & 56 & 81 & 87 & 73 \\
\hline Material and technical support & 74 & 86 & 71 & 75 \\
\hline Management & 57 & 76 & 75 & 64 \\
\hline Teaching & 72 & 95 & 88 & 79 \\
\hline Relevance of disciplines & 67 & 90 & 79 & 74 \\
\hline $\begin{array}{c}\text { Identification with the } \\
\text { profession }\end{array}$ & 64 & 81 & 75 & 69 \\
\hline Theoretical training & 68 & 86 & 79 & 74 \\
\hline Practical training & 67 & 71 & 71 & 68 \\
\hline Practice & 57 & 57 & 71 & 60 \\
\hline Conditions for self-realization & 74 & 81 & 71 & 74 \\
\hline Psycho-emotional comfort & 69 & 86 & 79 & 74 \\
\hline Electronic environment & 72 & 86 & 62 & 72 \\
\hline Interest & 84 & 95 & 88 & 87 \\
\hline
\end{tabular}

Overall, it can be stated that the satisfaction index is higher in the Master's degree graduates, as well as in graduates of both Master's and Bachelor's degrees in the university compared to those with the Bachelor's degree alone. The satisfaction index is also higher among the graduates who studied in budget-funded places relative to those who paid for their 
education themselves. Finally, the satisfaction index is significantly higher in distance learning graduates compared to full-time graduates.

An intriguing result on the satisfaction index is obtained for the three groups of respondents formed based on the answer to the question "If you had to go to college again, would you choose the same institution?". The satisfaction index in the respondents who answered "yes" ( $30 \%$ of the sample) is 86 , in those who answered "no" ( $25 \%$ of the sample) -55 , and in those who found the question "difficult to answer" (45\% of the sample) -75 . Based on the analysis of the results on this question, we can assume that the condition for achieving maximum graduate loyalty which allows them to recommend the university to their friends and acquaintances is achieving a graduate satisfaction index equal to $86 \%$. This assumption is also supported by the fact that approximately the same satisfaction index $(87 \%)$ is demonstrated by the group of graduates of both Bachelor's and Master's programs, i.e. those who have already demonstrated a high degree of loyalty to the university. The development of a holistic loyalty program is viewed by modern researchers as a factor of university competitiveness [10], student loyalty is growing to become the basis for the financial well-being of universities in the contemporary world.

\subsection{Importance ranking of satisfaction factors}

Foreign higher education institutions distinguish between the objective and subjective education quality indicators and assess both the demand for their graduates in society and students' own perception of their educational experience at the university [11]. As a part of the study, we compiled a rating of the importance of satisfaction factors reflecting the respondents' direct assessment which is more subjective. The rating places the factors indicated by the respondents when answering the direct question: "What factors, in your opinion, play the most important role in achieving a high quality of university education? Please choose 3 positions".

The leading factors ended up being "The professional level of the teachers" (32), "Relevance of the content of disciplines" (26), "Educational process management" (19), "Practical professional training" (16), "Development of interest and professional motivation" (15), and "Psycho-emotional comfort" (14). The results can be used in advertising and information campaigns by emphasizing the professionalism of teachers and disclosing the nomenclature of academic disciplines in each direction of training in detail to provide comprehensive information on the order and quality of the educational process.

\section{Discussion}

One of the main indicators of university graduates' satisfaction with educational programs indicated by researchers is the fact of employment in the obtained profession [8, 12-14].

The results obtained in our study are as follows: $25 \%$ of the respondents work according to their specialty, $40 \%$ work in a different specialty, and $35 \%$ of the respondents are unemployed. The dynamics of this indicator for different graduation years can serve as a reference point for the intra-university education quality management system, as well as the material for advertising self-presentation of the university in the market of educational services.

According to the survey results, $17.9 \%$ of the respondents feel a high degree of identification with the obtained profession, an average degree of self-identification is found in $71.8 \%$, and a low degree - in $10.3 \%$. Noteworthily, professional identification correlates with the level of graduates' theoretical training [9] and the range of developed competencies [15: 20]. 
For a more in-depth discussion, in addition to the obtained quantitative results, the conducted study involved qualitative sociological methods - open-ended questions and interviews. Overall, the advantages, disadvantages, and recommendations noted by the graduates in open-ended questions circle the previously identified factors and indicators with one exception: several respondents point to the need for universities to work on the employment of graduates.

\section{Conclusion}

The pilot study conducted to develop a system for the assessment of university graduates' satisfaction and conduct its monitoring proposes and tests the following instruments.

The factors of the quality of professional education programs that, as we believe, together form graduates' satisfaction with them are proposed. Individual indicators of satisfaction are also presented. A questionnaire is developed based on the identified factors and indicators. The results of the questionnaire allow calculating a satisfaction index based on the average assessment of each factor and indicator for different groups of graduates (according to the year of graduation, different forms of training, source of education financing, region of residence, age, etc.). The introduction of qualitative research into the university graduate satisfaction monitoring system supplements the quantitative method and provides the opportunity to quickly register and account for new factors and conditions emerging in the social reality and university life that may call for appropriate consideration and response measures. Moreover, the opportunity to express one's opinion on the quality of education at the university anonymously has a positive psychological effect: overall, the expressed positive and negative emotions normalize the consumer's assessment and generally favor the university brand in the market of educational services.

\section{References}

1. V.M. Filippov, Zh.V. Puzanova, Theory and Practice of Social Development, 24, 12-15 (2015)

2. E.D. Bespalova, E.A. Zhirnova, Reshetnev readings, 2, 463-465 (2015)

3. E.V. Mikhalkina, O.Ia. Gerasimova, State and Municipal Management. Scholar Notes, 4, 76-84 (2019)

4. S.S. Kotova, I.I. Khasanova, The Education and Science Journal, 9(138), 43-61 (2016)

5. D.O. Kriukov, Vestnik of Saint Petersburg University, Ser. 12, 2(1), 107-114 (2009)

6. Natsionalnyi standart Rossiiskoi Federatsii sistemy menedzhmenta kachestva.

Osnovnye polozheniia i slovar [National Standard of the Russian Federation for Quality Management Systems. Main Provisions and Glossary] (Standartinform, Moscow, 2019). Accessed on: September 9, 2020. [Online]. Available:

http://docs.cntd.ru/document/1200124393

7. Iu.R. Vishnevskii, D.Iu. Narkhov, RUDN Journal of Sociology, 19(2), 289-301 (2019)

8. D.G. Sandler, A.D. Sushchenko, P.D. Kuznetsov, T.E. Pechenkina, University Management: Practice and Analysis, 22(3), 73-83 (2018)

9. I.S. Kazakova, M.V. Pereverzeva, Scientific Notes of the Russian State Social University, 18, 1(150), 92-99 (2019)

10. C. Munteanu, C. Ceobanu, C. Bobâlca, O. Anton, International Journal of Public Sector Management, 23(2), 124-140 (2010)

11. B.Y. Grace, J.-H. Kim, Quality of Life, 3(1), 1-21 (2008) 
12. R.A. Abramov, I.V. Pronina, E.Iu. Khalatenkova, The Education and Science Journal, 10(139), 91-106 (2016)

13. A.D. Sushchenko, P.D. Kuznetsov, T.E. Pechenkina, Theory and Practice of Social Development, 10(140), 30-36 (2019)

14. L.G. Miliaeva, Analiz uspeshnosti trudoustroistva vypusknikov vuzov v usloviiakh kompetentnostnogo podkhoda [Analysis of university graduates' employment success of under the competency-based approach], in Human Resource Management. Collection of scientific works, 2, 176-186 (Novosibirsk State University of Economics and Management, Novosibirsk, 2016)

15. N.E. Shafazhinskaya, V.M. Shcherbinina, E.Y. Ivanova, T.E. Belyakova, M.V. Pereverzeva, Humanities and Social Sciences Reviews, 8(1), 42-46 (2020) 